\title{
Modelling polar bear maternity den habitat in east Svalbard
}

\author{
Benjamin Merkel ${ }^{1}$, Jon Aars ${ }^{1}$ \& Glen E. Liston ${ }^{2}$ \\ ${ }^{1}$ Norwegian Polar Institute, Fram Centre, Tromsø, Norway; \\ ${ }^{2}$ Cooperative Institute for Research in the Atmosphere, Colorado State University, Fort Collins, CO, USA
}

\begin{abstract}
We evaluated a novel tool that predicts possible maternity den habitat of the polar bear (Ursus maritimus) based on a physical snow transport model, a digital terrain model and weather data. We observed and compared den locations in three important denning areas in east Svalbard (Kongsøya, $n=288$; Svenskøya, $n=86$; Hopen, $n=115$ ) with modelled snowdrift distributions for 24 years. Accounting for a likely position uncertainty of $100 \mathrm{~m}, 69 \%$ of all dens were located within year-specific modelled snowdrifts. These covered on average $1.8 \%, 2.1 \%$ and $24.7 \%$ of the three study islands, respectively. Our snowdrift model accurately predicted maternity den positions $\left(R^{2}=0.42\right.$, area under the receiving operating characteristic curve $[\mathrm{AUC}]=0.85)$. A model based on slope and altitude, also predicted den positions reasonably well $\left(R^{2}=0.35\right.$, AUC $=0.88)$. Habitat maps identifying both current and future areas for maternity denning will become important in managing the Barents Sea population as well as other Arctic populations where changes in sea-ice conditions alter the accessibility to traditional denning areas.
\end{abstract}

\section{Keywords \\ Climate change; reproduction; SnowDens-3D; snowdrift model; terrain model; topography}

\section{Correspondence}

Benjamin Merkel, Norwegian Polar Institute, Fram Centre, PO Box 6606 Langnes, NO-9296 Tromsø, Norway. E-mail:merkel_benjamin@mailbox.org

\section{Abbreviations}

AIC: Akaike information criterion AUC: area under the receiving operating characteristic curve

BIC: Bayesian information criterion DAAG: Data Analysis and Graphics data and functions (software) NORA10: Norwegian Reanalysis Archive

To access the supplementary material, please visit the article landing page

\section{Introduction}

The Arctic is warming and sea-ice extent is decreasing (Stocker et al. 2013). Sea-ice-dependent animals such as the polar bear (U. maritimus) will be particularly affected (Laidre et al. 2008). This apex predator has a circumpolar distribution (Amstrup 2003) and uses the Arctic sea ice as a primary habitat and hunting ground for its main prey species: ringed seals (Pusa hispida) and bearded seals (Erignathus barbatus) (Amstrup 2003).

Polar bears in eastern Svalbard typically exhibit seasonal migrations (Mauritzen et al. 2001) as well as denning and spring feeding site fidelity (Zeyl et al. 2009; Lone et al. 2013). Although polar bears of all ages and both sexes may go into temporary dens during periods with harsh weather or low food availability in winter (Amstrup 2003), only pregnant females display prolonged denning (Messier et al. 1994). Dens in most areas in Svalbard are located only on land, although in the Beaufort Sea dens have also traditionally been found on land-fast ice or on multiyear sea ice (Lentfer 1975; Amstrup \& Gardner 1994; Fischbach et al. 2007). Pregnant females usually enter maternity dens sometime in October to
mid-December (Amstrup 2003), where they give birth to one to three altricial cubs in mid-November to midJanuary (Harington 1968). Den emergence varies from February to May (Amstrup 2003), and in Svalbard has a peak in early April (Andersen et al. 2012; Aars 2013). In most populations, cubs stay with their mothers for 2.5 years (Amstrup 2003). Consequently, adult females will enter a maternity den every third year if cubs are successfully weaned (Ramsay \& Stirling 1986). In Svalbard, the estimated cub survival fraction is approximately 0.4 in the first year (Aars unpubl. data). Therefore, on average, it is more typical for pregnant females to enter a den every second year (Wiig 1998).

An estimated 2650 (Aars et al. 2009), polar bears inhabit the Barents Sea. This shallow (average $230 \mathrm{~m}$ ) shelf sea is situated in the European Arctic and includes the Svalbard and Franz Josef Land archipelagos. Most polar bear dens in Svalbard are found in the east of the archipelago (Andersen et al. 2012). Derocher et al. (2011) demonstrated that the maternity den distribution in Svalbard is affected by the timing of the arrival of sea ice around the archipelago in autumn. If pregnant females are not able to reach their accustomed denning sites they 
have to find suitable terrains in other regions (Derocher et al. 2004; Fischbach et al. 2007). In addition to sea ice allowing bears to reach the areas in autumn, a snow cover and the presence of snowdrifts adjacent to abrupt banks, bluffs and cliffs and sea-ice pressure ridges are necessary for denning to occur. Sufficient snow must accumulate by late November for bears to dig dens (Larsen 1985).

Because sea ice distribution and extent are changing, it is likely that key denning areas in Svalbard may often be inaccessible by bears in future years. Hence, it is important to be able to assess not only the terrain-related factors of denning habitat but also how denning habitat can be affected by variable weather patterns in a given year. This study explores whether a physically-based snow transport model can adequately describe available polar bear maternity denning habitat in Svalbard when combined with a digital terrain model and local weather data.

\section{Methods}

\section{Study area}

The study area comprised islands-Kongsøya $\left(78.9^{\circ} \mathrm{N}\right.$, $\left.28.7^{\circ} \mathrm{E}\right)$, Svenskøya $\left(78.75^{\circ} \mathrm{N}, 26.6^{\circ} \mathrm{E}\right)$ and Hopen $\left(76.55^{\circ}\right.$ $\left.\mathrm{N}, 25^{\circ} \mathrm{E}\right)$-in the eastern part of the Svalbard Archipelago $\left(74-81^{\circ} \mathrm{N}, 10-34^{\circ} \mathrm{E}\right)$, Norway (Fig. 1). Kongsøya is an island, $40 \mathrm{~km}$ long and up to $8 \mathrm{~km}$ wide, and is dominated in the west and east by mountainous areas $12 \mathrm{~km}$ and $8 \mathrm{~km}$ long, respectively, with a maximum elevation of $320 \mathrm{~m}$. The neighbouring island, Svenskøya, is $22 \mathrm{~km}$

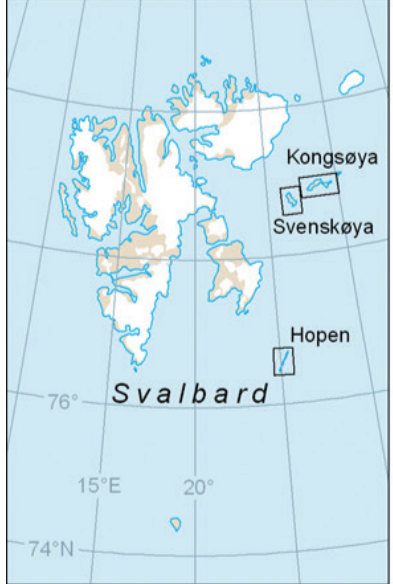

- Polar bear maternity den

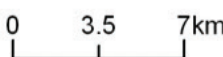

(c) Norwegian Polar Institute 2014
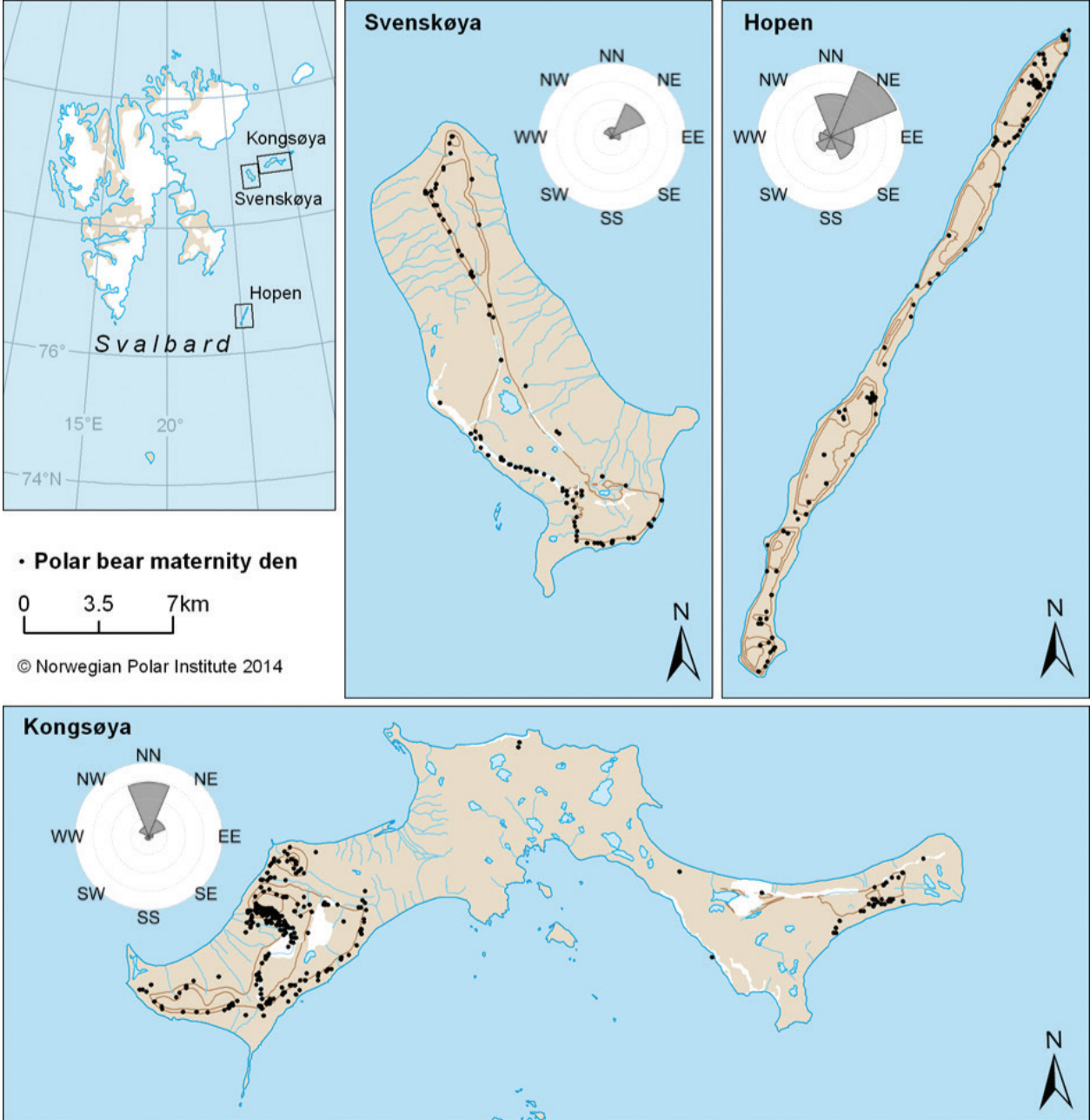

Fig.1 Location of the three study islands within the Svalbard Archipelago (top left) and the distribution of all recorded polar bear maternity dens ( $n=489$ ) on these islands, accumulated from 1972 to 2012 . White shapes illustrate glaciated areas while brown contour lines denote 100 m elevation increments. Insets in each panel depict circular histograms of total accumulated snow depth (in metres) for each wind direction and each island in the time period 1966-2011. The maximum of each histogram is scaled to 2500 m accumulated snow over the 46 years considered. 
long and up to $8 \mathrm{~km}$ wide, with a central mountain ridge ranging from the north-west to the south-east with elevations of up to $290 \mathrm{~m}$. The third island, Hopen, is $37 \mathrm{~km}$ long and up to $2 \mathrm{~km}$ wide, with eight plateaus and a highest elevation of $385 \mathrm{~m}$. It is unlike the other two islands in that it is characterized by near sheer cliffs dropping from these plateaus into the ocean.

\section{Polar bear maternity den data}

Polar bear maternity dens were opportunistically recorded by visual inspection during ground and aerial surveys in Svalbard from 1972 to 2012 (Larsen 1972; Hansson \& Thomassen 1982; Larsen 1986; Andersen et al. 2012). All surveys were conducted from March to May. Ground surveys were conducted on skis or snowmobiles and aerial surveys were conducted by using helicopters or fixedwing aircrafts from altitudes between 25 and $100 \mathrm{~m}$. Only denning locations in Kongsøya, Svenskøya and Hopen were used for this study since these islands represent important denning areas and the majority of surveys were conducted there (Andersen et al. 2012). Survey effort varied both spatially and temporarily between years. When skis were used, the areas covered were more local, and concentrated on prime denning habitat (particularly east Kongsøya). The number of observation days also varied with weather conditions; for example, in some years, dens were difficult to locate after windy weather when openings were covered by drifting snow.

\section{Meteorological forcing}

To drive our analyses, long-term Norwegian Reanalysis Archive (NORA10) data were provided by the Norwegian Meteorological Institute. These hourly data are available at a $10-\mathrm{km}$ spatial resolution, spanning the time period from 1958 through present, over the north-eastern North Atlantic (Reistad et al. 201 1; Furevik \& Haakenstad 2012; Reistad et al. 2015). To prepare the meteorological data for this study, the 10-km gridded MET data were downscaled, using MicroMet (Liston \& Elder 2006) to a l-km grid covering all of Svalbard (Van Pelt et al. 2016). Then the meteorological data time series corresponding to the $1-k m$ grid cell closest to the centre of each of the three islands was aggregated to daily values and extracted and used to force the snow transport model, SnowDens-3D.

\section{SnowDens-3D}

SnowDens-3D (Liston et al. 2016) is a physically based, spatially distributed numerical snow model that simulates snow-depth evolution resulting from precipitation and blowing-snow redistribution over virtually any topographically variable landscape. SnowDens-3D mimics the physical interactions of snow, wind, topography and landcover, to determine when, where and how much snow is transported and deposited in response to variations in weather and topography. The resulting system predicts the locations, timing and evolution of snowdrifts suitable for polar bear dens, and reproduces the controlling factors that determine key polar bear snowdrift denning habitat characteristics such as snow depth and distribution. In Arctic Alaska, Liston et al. (2016) found that, for the 31 den locations where position accuracy estimates were known, 97\% of the time SnowDens-3D produced a snowdrift suitable for denning within that distance.

Pregnant polar bears in Svalbard normally enter dens from October through early December (Lønø 1970; Wiig 1998). Therefore, SnowDens-3D was applied to a $20 \times 20 \mathrm{~m}$ resolution digital terrain model (Norwegian Polar Institute) and run from 1 August through 30 November for each year from 1966 to 2011 with a daily time step; this period encompassed the typical period for snow to accumulate before bears went into their maternity dens. For the simulations presented herein, one modification was made to the SnowDens-3D version described in the work of Liston et al. (2016): the blowing snow horizontal transport fluxes simulated by SnowDens-3D were increased by a factor of 20 in order to account for the turbulent eddies that transport snow farther downwind than the grid cells nearest to the lee lip of the topographic distributions. This was applied over the entire gridded digital terrain model. The net effect of this change was to extend the snowdrifts farther downwind from the lee-slope edges; this better matched our visible imagery/observations of snowdrifts on the steep mountain slopes of the three islands.

\section{Environmental variables}

It is not possible to collect absence data for maternity dens. Therefore, we randomly generated 10 pseudo-absence locations for each observed den (Barbet-Massin et al. 2012) within the island boundaries to represent the landscape potentially available as denning habitat on the island where the den was found. Pseudo-absence locations are analogous to used versus available locations as defined by Johnson et al. (2006).

Precision in the recorded positions of observed dens vary. Some were observed from a distance and drawn on a map, others had GPS coordinates taken from a helicopter hovering above the den. In later years, triangulations were used in some cases and, for dens known to be deserted, a GPS position was taken on the den. We assumed few dens were placed correctly within metres, 
but that most recorded positions would be within $100 \mathrm{~m}$ from the real location. We did, however, test for three levels of uncertainty: (1) accurate (radius of uncertainty: $20 \mathrm{~m}$, i.e., one pixel); (2) moderate accurate (100 m) and (3) inaccurate $(250 \mathrm{~m})$. At any level of uncertainty, dens recorded within a pixel with insufficient modelled snow depth were assumed to have been observed in the closest pixel with sufficient snow depth, given that the distance between den observation and pixel with sufficient snow depth for denning was less than or equal to the uncertainty level for that model. Snow depth for each den location and each pseudo-absence location was extracted from the year-specific snow distribution maps as categorical variables with two levels: (1) sufficient and (2) insufficient snow depth to establish a maternity den. As a cut-off point, a minimum snow depth value of $2 \mathrm{~m}$ was used to define viable den habitat (Liston et al. 2016).

To assess whether other geographical factors influence denning locations, distance to the closest stream was included as a categorical variable with four levels (0-100 m, 100-200 m, 200-300 m and > $300 \mathrm{~m}$ ). Locations of streams were obtained from the Mapping Section of the Norwegian Polar Institute. Altitude and slope were extracted from the digital terrain model as an average of all pixels for each uncertainty level. Aspect was not included in the analysis since the survey and observation methods biased polar bear maternity den observations with regard to this variable (e.g., Hansson \& Thomassen 1982).

\section{Statistical analysis}

The predictive capabilities of the SnowDens-3D model were analysed using logistic generalized linear models with binomial family and logit link. Models were fitted using $\mathrm{R}$ (version 3.0.2, R Development Core Team 2018) and the dredge function from the MuMIn package (Bartoń 2013) to test all possible model combinations for the three different levels of uncertainty. To assess the fit of SnowDens-3D, a snowdrift model set and a terrain model set for each uncertainty level were developed in which the response variable was presence versus pseudo-absence of polar bear maternity dens. The snowdrift model set included the predictor variables snow (a factor with two levels: sufficient or insufficient snow present as modelled by SnowDens-3D), distance to the closest stream and island (a factor with three levels: Kongsøya, Svenskøya and Hopen). The terrain model set included the predictor variables: slope in degrees, altitude in metres and island.

Initially, we checked whether any pair of predictor variables were correlated. Spearman's rank correlation test was used to assess continuous variables while chi-squared contingency table tests were used to test categorical variables. If two variables were correlated $\left(p<0.05\right.$ and/or $\left.\left|r_{s}\right|>0.7\right)$ the one with the most biological relevance for polar bear denning habitat selection was included in the models. Linearity of continuous variables (slope and altitude) was explored by modelling and visually inspecting each predictor variable against the response on a logit scale with generalized additive modelling and the binomial family using the package mgcv (Wood 2006). Both slope and altitude showed signs of nonlinear relations with the response variable, and hence a second-order polynomial for each variable was added. The best model for each snowdrift set and each uncertainty level was selected using BIC, and BIC weights, rather than AIC, to penalize model complexity and select the simplest model. Goodness of fit for all models was assessed using Nagelkerke's $R^{2}$ (Nagelkerke 1991), which quantifies the proportion of the total variance explained by a model. The predictive accuracy of each snowdrift model was calculated using the DAAG package (Maindonald \& Braun 2010). The data were randomly split into 10 folds, which were in turn removed and the remaining data used to fit the logistic regression and to predict the deleted observations. This was repeated 25 times and the mean and standard deviation of the internal cross-validation presented. Model discrimination was tested by calculating the AUC (Fielding \& Bell 1997). The AUC value ranged from 0.5 for no discrimination ability to 1.0 for perfect discrimination (Pearce \& Ferrier 2000). Further, sensitivity analyses were performed with regards to the cut-off value for the minimum required snow depth for a bear to establish a den.

Linear regressions were used to assess possible correlations of year and number of maternity dens, with the proportion of each island covered by snow deeper than the minimum required snow depth. To compare the different islands, the proportions have been standardized.

\section{Results}

A total of 489 maternity dens (115 on Hopen, 288 on Kongsøya, 86 on Svenskøya) were observed from 1972 to 2012 within the study area (Table 1).

The main snow carrying wind directions were north and north-east for Kongsøya and Svenskøya and north, north-east, east and south-east for Hopen during the period 1966-2011. Most snow was predicted to come from the north and north-east for all three islands. Hopen received most, and Svenskøya the least, amount of snow for all wind directions (Fig. 1).

For the time period 1966-2011, year-specific modelled snowdrifts, sufficient for den creation, covered 


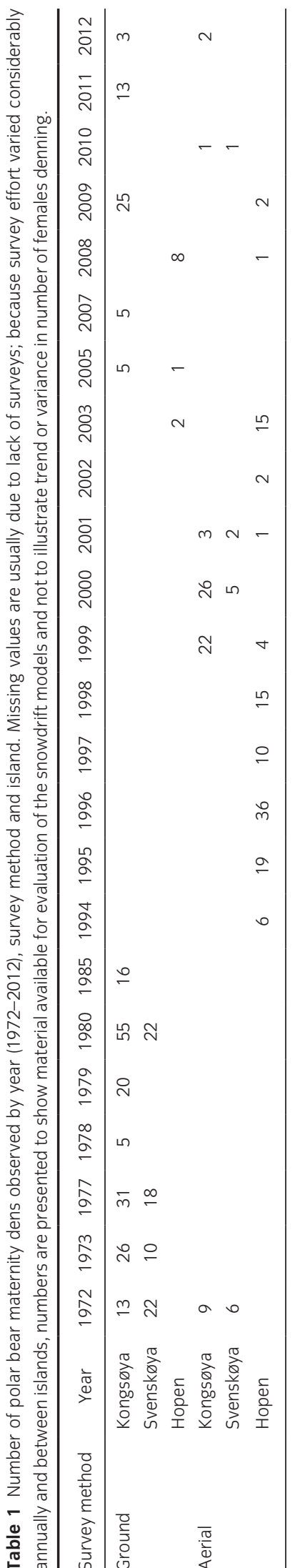

on average $1.8 \%$ (absolute $3.4 \mathrm{~km}^{2}$, range: $0.3-4.6 \%$ / 0.6-8.8 $\mathrm{km}^{2}$ ) of Kongsøya (Fig. 2), $2.1 \%$ (2.9 km², range: $0.5-4.2 \% / 0.7-5.7 \mathrm{~km}^{2}$ ) of Svenskøya and $24.7 \%$ (11.3 km², range: $13.0-36.1 \% / 6.0-16.5 \mathrm{~km}^{2}$ ) of Hopen. Snowdrift coverage was not sensitive to the cut-off value used as minimum required snow depth $(2 \mathrm{~m})$ for polar bear dens on Kongsøya and Svenskøya (Supplementary Fig. S1). Hopen displayed more variability, but at a higher proportion covered. The proportion of the study islands covered by sufficient snow depth was positively correlated with year independent of the three study islands $(0.3 \%$ increase per decade in Kongsøya and Svenskøya and $1.0 \%$ increase per decade in Hopen, $\left.p<0.001, R^{2}=0.08\right)$. A high proportion of dens were in modelled snowdrifts using the most probable uncertainty of $100 \mathrm{~m}$ for all three islands (Kongsøya $=60 \%$, Svenskøya $=66 \%$, Hopen $=95 \%$ ).

No set of predictor variables were correlated. The best snowdrift model included snow and island, while the best terrain model included four continuous variables (altitude, altitude ${ }^{2}$, slope, slope ${ }^{2}$ ) and island (Fig. 3, model coefficient estimates as well as marginal plots for the other uncertainty levels are shown in the appendix). The best snowdrift model had the lowest BIC for the most probable assumed uncertainty of $100 \mathrm{~m}$ (Table 2; results for the other two uncertainty levels are shown in Supplementary Table S1). The explained variance for the best snowdrift model $\left(R^{2}=0.42\right)$ was higher than that for the best terrain model $\left(R^{2}=0.35\right)$. The proportion of observations correctly classified was consistently high at 0.9 for all considered models (Table 2).

\section{Discussion}

The motivation for developing a tool to map polar bear denning habitat was to make it possible to predict likely changes in the distribution of the areas suited for denning in future years. With sea-ice loss, drastic changes in distributions of dens have already been seen in Svalbard. The historically important denning areas in the south-east of the archipelago now host few denning females in winter because in recent years sea ice often formed too late in autumn (Derocher et al. 2011; Aars 2013).

Year-specific modelled snowdrifts were able to describe maternity den habitat with good accuracy $\left(R^{2}=0.42\right.$ and AUC $=0.85)$. Additionally, Liston et al. (2016) showed that SnowDens-3D also performed well in northern Alaska, which is dominated by a flat, featureless topography interrupted by river and coastal banks. With detailed topographic maps and weather data, we can map denning habitat for the whole Svalbard archipelago, and tell: (1) where the most likely alternative areas for 

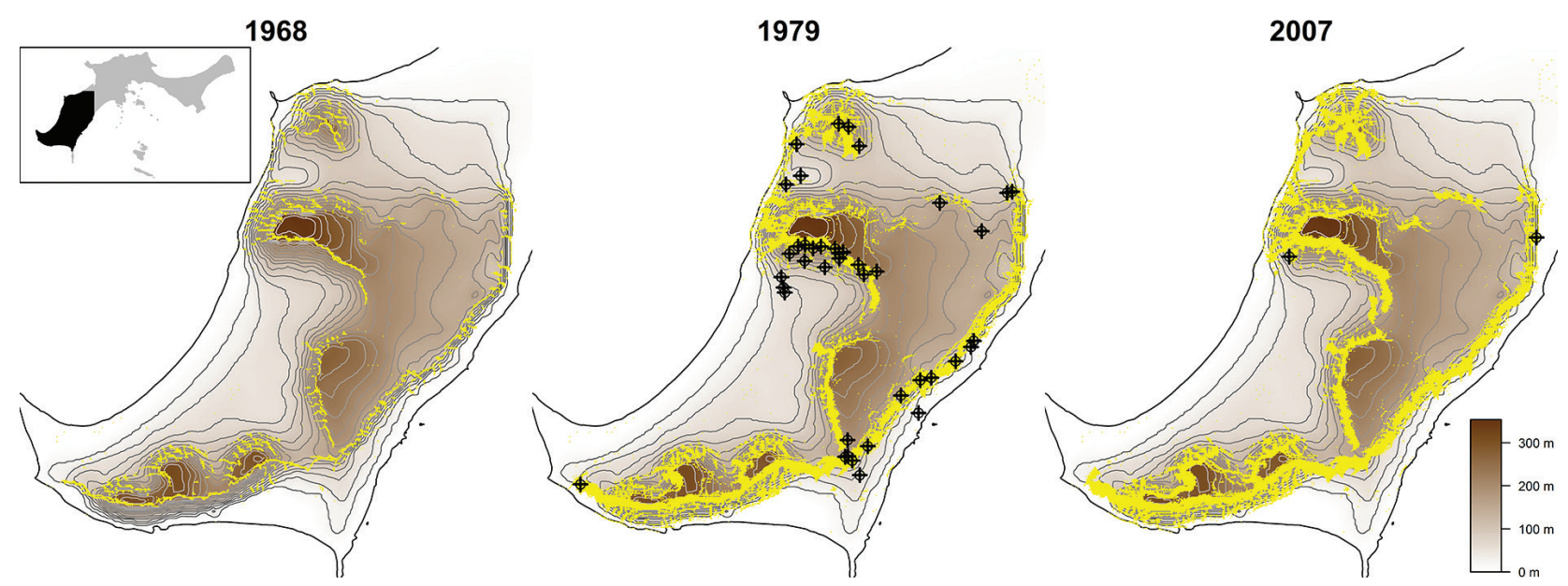

Fig. 2 Digital elevation model of west Kongsøya (black area in inset box) in shades of brown. Modelled snowdrifts of sufficient depth for den creation (yellow) for the autumn of years with minimum (1968) and maximum (2007) snowdrift coverage as well as maximum number of dens observed (1979). Observed dens found in subsequent years (none in spring 1969, 41 in spring 1980 and two in spring 2008) are added as black symbols (+) with a $100 \mathrm{~m}$ buffer to denote uncertainty (black circles).
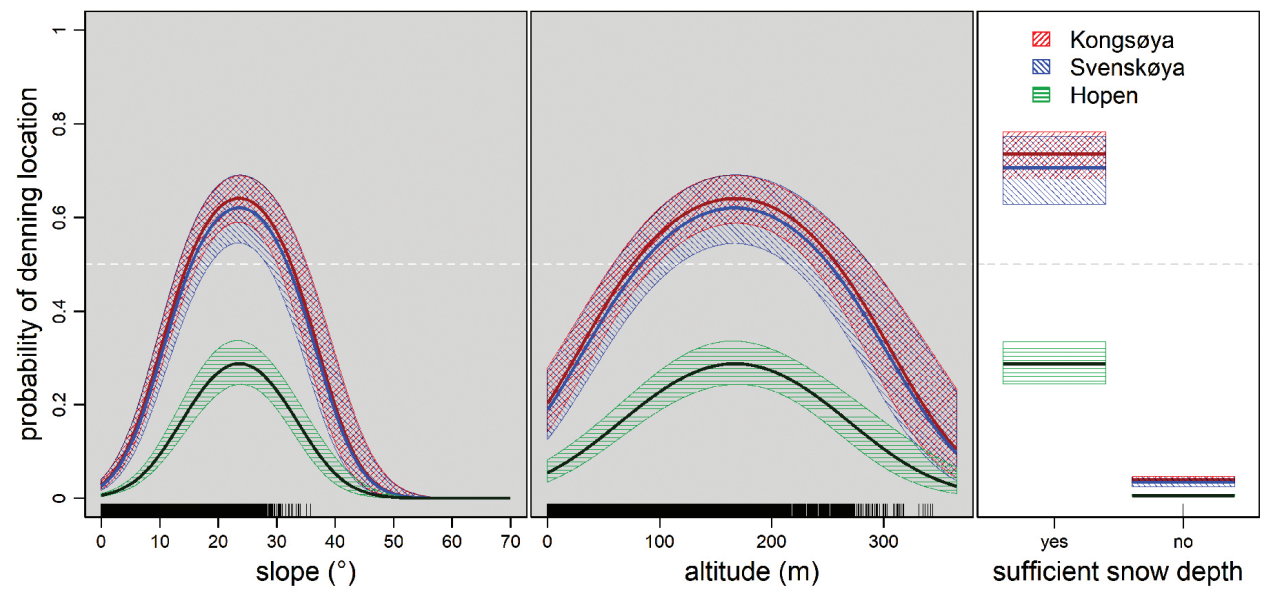

Fig. 3 Marginal plots for the best fitted terrain model (grey background) as well as snowdrift model (white background) for the 100-m uncertainty level. The effect of each variable on the predicted probability of presence of a polar bear maternity den is shown by varying one predictor variable and keeping the other constant. The 95\% confidence intervals are shown as shaded areas. The distribution of the predictor variables is shown in the bottom of each panel. Note that results for Svenskøya and Kongsøya overlap to a large extent (see model coefficients in Supplementary Tables S2 and S3 and marginal plots for the other uncertainty levels are provided in Supplementary Fig. S2).

denning are, given that the bears failing to reach islands in the south-east need alternative sites; (2) with predicted changes in climate, model how both availability and distribution of denning habitat may change in future years. In combination with models of sea-ice distribution, and knowledge of prey distributions in different seasons, this will enable us to better manage a polar bear population experiencing significant changes in its living area.

The terrain model also performed well $\left(R^{2}=0.35\right.$, $\mathrm{AUC}=0.88)$. Most dens were found in steep terrain with slopes of 15-35 degrees at 100-250 m altitude (Fig. 3). The snowdrift model will be superior when weather data are available, but the terrain model may be useful to make initial habitat maps, telling where the terrain will allow snow to accumulate providing enough precipitation and wind from the right direction. Although wind direction was very prominent from the north and northeast at the study islands, wind directions change between years. It is valuable to produce habitat maps that include areas that may be of minimal importance in almost all 
Table 2 The four best models for the snowdrift model set, as well as the terrain model set (final four rows of the table, set in boldface), at 100-m uncertainty according to BIC and BIC weights. Dashes indicate that the given variable was unavailable for the given model set.

\begin{tabular}{|c|c|c|c|c|c|c|c|c|c|c|c|c|c|c|}
\hline \multicolumn{7}{|c|}{ Model variables } & \multirow[t]{2}{*}{$d f$} & \multirow[t]{2}{*}{$\mathrm{BIC}$} & \multirow[t]{2}{*}{$\Delta \mathrm{BIC}$} & \multirow[t]{2}{*}{ BIC weight } & \multirow[t]{2}{*}{$A \cup C$} & \multirow[t]{2}{*}{$R^{2 f}$} & \multirow[t]{2}{*}{$C V^{g}$} & \multirow[t]{2}{*}{$s d c v^{h}$} \\
\hline$r v r^{a}$ & snow $^{b}$ & alt ${ }^{c}$ & $a l t^{2}$ & $s / p^{d}$ & $s / p^{2}$ & $10^{\mathrm{e}}$ & & & & & & & & \\
\hline & + & - & - & - & - & + & 4 & 2151 & 0.0 & 1.00 & 0.85 & 0.42 & 0.94 & $<0.001$ \\
\hline+ & + & - & - & - & - & + & 7 & 2176 & 25.0 & 0.00 & 0.84 & 0.42 & 0.94 & $<0.001$ \\
\hline \multirow[t]{2}{*}{+} & + & - & - & - & - & & 5 & 2300 & 149.0 & 0.00 & 0.84 & 0.38 & 0.92 & 0.001 \\
\hline & + & - & - & - & - & & 2 & 2306 & 155.0 & 0.00 & 0.81 & 0.37 & 0.91 & $<0.001$ \\
\hline- & - & + & + & + & + & + & 7 & 2386 & 234.8 & 0.00 & 0.88 & 0.35 & 0.91 & 0.001 \\
\hline- & - & + & & + & + & + & 6 & 2423 & 272.0 & 0.00 & 0.87 & 0.34 & 0.91 & 0.001 \\
\hline- & - & & + & + & + & + & 6 & 2442 & 290.8 & 0.00 & 0.87 & 0.33 & 0.91 & 0.001 \\
\hline- & - & & & + & + & + & 5 & 2446 & 294.5 & 0.00 & 0.87 & 0.33 & 0.91 & 0.001 \\
\hline
\end{tabular}

${ }^{a}$ Categorical, distance to the nearest stream. ${ }^{b}$ Presence or absence of sufficient snow depth. ${ }^{\mathrm{c} A l t i t u d e}(\mathrm{~m}) .{ }^{\mathrm{d}}$ Slope $\left({ }^{\circ}\right)$. ${ }^{e}$ Island factor (Kongsøya, Svenskøya, Hopen). ${ }^{\mathrm{f}}$ Nagelkerke's $R^{2} .{ }^{8} \mathrm{Cross}-\mathrm{validation}$. ${ }^{\text {SS}} \mathrm{Standard}$ deviation of cross-validation.

years, but that may be most important in years with atypical weather conditions.

Models predicted that Hopen had so much of the area covered with snowdrifts in any year (i.e., at the minimum $6 \mathrm{~km}^{2}$ ), that it would be unlikely that availability of snowdrifts would be a limiting factor to bears searching for den sites. However, Kongsøya and Svenskøya-two of the major denning areas for polar bears in Svalbardhad only on average $2 \%$ of the area covered with sufficient snow depths corresponding to less than $4 \mathrm{~km}^{2}$ of available denning habitat on these islands. Additionally, this varied significantly among years, ranging from 0.6 to $8.8 \mathrm{~km}^{2}$. The coverage of modelled snowdrifts showed a significant increase from 1966 to 2011 . A simulation for the whole of Svalbard by Van Pelt et al. (2016), based on the same set of weather data, shows that there has been an increase in snow precipitation in the east and north, but at the same time a decrease in the south-west area of the archipelago. It may therefore be that there are improved conditions for suitable den sites in areas where polar bears will not be able to get to on account of lack of sea ice between these areas and the areas where the bears hunt in summer, while alternative areas further west that recently seem to have experienced an increase in denning bears (Andersen et al. 2012) may experience a reduction in suitable sites. It is, however, not possible based on recent data to state if availability of suitable snowdrifts is limiting in any of the actual denning areas. Although milder weather may, in some areas, lead to more snow and more available denning habitat, mild spells also lead to more frequent episodes of rain on snow. Such episodes have been shown to impact terrestrial wildlife significantly in Svalbard (Stien et al. 2012; Hansen et al. 2013). They could lead to fatal collapses of maternity dens and the death of mothers and cubs (Clarkson \& Irish 1991).

Both the snowdrift model and the terrain model showed increased fit by including the islands as a variable. This was most likely driven by the island Hopen, which, due to its topography and prevailing weather conditions, has a much higher proportion of its area covered by sufficient snow drifts. All three islands are too small to have any areas far from the coast. In other areas, distance to the coast may be a parameter that could improve the model, since the distance a mother has to walk with her cubs to reach the coast for ringed seal hunting may be of importance.

SnowDens-3D simulations and hence the snowdrift models depend strongly on the quality of the meteorological inputs, in particular, air temperature, precipitation, wind speed and wind direction. While the NORAl0 data we used are considered the best available for this region, it may still suffer from important deficiencies. For example, most polar bear dens are in topographically variable terrain (e.g., ridges, gullies and cut-banks) that impact the local wind speeds that are not resolved by the $10-\mathrm{km}$ NORA10 data. In addition, the reanalysis forcing data includes changes in assimilated observation datasets that can impact trends in the simulated den-habitat distributions. Therefore, the simulated trends may not be related to actual trends in atmospheric conditions. Finer-grained digital elevation models may thus improve the den habitat models further. While areas with rough topography, like Hopen, will likely have many places with sufficient snow drifts in any year, and that may be part of the reason why it has had among the highest densities of dens in the Arctic (Larsen 1985), less profound structures can be important in areas where most of the terrain is flat. In Alaska, banks along the mainland coast or on smaller 
islands with only a few metres height provide drifts for dens in large flat areas with few good alternatives (Durner et al. 2001; Durner et al. 2003; Durner et al. 2013).

\section{Conclusion}

With current and predicted changes in sea-ice availability and a milder climate, the distribution of both polar bears and their prey species are expected to experience significant changes in distribution, densities and habitat use. Habitat maps identifying both current and future areas for maternity denning will be important in future management of the Barents Sea population and other Arctic populations experiencing similar changes.

\section{Acknowledgements}

The authors thank Øystein Overrein for sharing his significant knowledge regarding denning behaviour and local conditions in the denning area of Kongsøya based on his three years of fieldwork. The authors also thank Magnus Andersen for useful discussions. Both have participated in the collection of some of the den positions used in this study. Den positions were further acquired by many people from the 1970s until recently, significant among them being Rasmus Hansson, Jørn Thomassen, Thor Larsen, Øystein Wiig, Tommy Sandal and Andrew Derocher. The authors thank Hilde Haakenstad and Jan Erik Haugen from the Norwegian Meteorological Institute for work on the NORAl0 weather data for the snow drift model.

\section{Disclosure statement}

GEL is the author and developer of SnowDens-3D and has an interest in its successful application.

\section{Funding}

This study was funded by the Svalbard Environmental Protection Fund. The World Wildlife Fund has sponsored many of the polar bear denning surveys in Svalbard.

\section{References}

Aars J. 2013. Variation in detection probability of polar bear maternity dens. Polar Biology 36, 1089-1096, doi: 10.1007/ s00300-013-1331-7.

Aars J., Marques T.A., Buckland S.T., Andersen M., Belikov S., Boltunov A. \& Wiig Ø. 2009. Etimating the Barents Sea polar bear subpopulation size. Marine Mammal Science 25, 35-52, doi: 10.1111/j.1748-7692.2008.00228.x.
Amstrup S.C. 2003. The polar bear, Ursus maritimus. In G.A. Feldhamer et al. (eds.): Wild mammals of North America: biology, management, and conservation. Pp. 587-610. Baltimore, MD: Johns Hopkins University Press.

Amstrup S.C. \& Gardner C. 1994. Polar bear maternity denning in the Beaufort Sea. The Journal of Wildlife Management 58, 1-10, doi: 10.2307/3809542.

Andersen M., Derocher A.E., Wiig O. \& Aars J. 2012. Polar bear (Ursus maritimus) maternity den distribution in Svalbard, Norway. Polar Biology 35, 499-508, doi: 10.1007/ s00300-01 1-1094-y.

Barbet-Massin M., Jiguet F., Albert C.H. \& Thuiller W. 2012. Selecting pseudo-absences for species distribution models: how, where and how many? Methods in Ecology and Evolution 3, 327-338, doi: 10.1111/j.2041-210X.2011.00172.x.

Bartoń K. 2013. MuMIn: multi-model inference: R package version 1.9.13. Accessed on the internet at https:// CRAN.R-project.org/package=MuMIn.

Clarkson P.L. \& Irish D. 1991. Den collapse kills female polar bear and two newborn cubs. Arctic 44, 83-84, doi: 10.14430/arcticl 522 .

Derocher A.E., Andersen M., Wiig O., Aars J., Hansen E. \& Biuw M. 2011. Sea ice and polar bear den ecology at Hopen Island, Svalbard. Marine Ecology Progress Series 441, 273-279, doi: 10.3354/meps09406.

Derocher A.E., Lunn N.J. \& Stirling I. 2004. Polar bears in a warming climate. Integrative and Comparative Biology 44, 163-176, doi: 10.1093/icb/44.2.163.

Durner G.M., Amstrup S.C. \& Ambrosius K.J. 2001. Remote identification of polar bear maternal den habitat in northern Alaska. Arctic 54, 115-121, doi: 10.14430/ arctic770.

Durner G.M., Amstrup S.C. \& Fischbach A.S. 2003. Habitat characteristics of polar bear terrestrial maternal den sites in northern Alaska. Arctic 56, 55-62, doi: 10.14430/ arctic602.

Durner G.M., Simac K.S. \& Amstrup S.C. 2013. Mapping polar bear maternal denning habitat in the National Petroleum Reserve-Alaska with an IfSAR digital terrain model. Arctic 66, 197-206, doi: 10.14430/arctic4291.

Fielding A.H. \& Bell J.F. 1997. A review of methods for the assessment of prediction errors in conservation presence/ absence models. Environmental Conservation 24, 38-49, doi: $10.1017 / \mathrm{s} 0376892997000088$.

Fischbach A.S., Amstrup S.C. \& Douglas D.C. 2007. Landward and eastward shift of Alaskan Polar bear denning associated with recent sea ice changes. Polar Biology 30, 1395-1405, doi: 10.1007/s00300-007-0300-4.

Furevik B.R. \& Haakenstad H. 2012. Near-surface marine wind profiles from rawinsonde and NORAl0 hindcast. Journal of Geophysical Research-Atmospheres 117, article no. D23106, doi: 10.1029/2012jd018523.

Hansen B.B., Grotan V., Aanes R., Saether B.-E., Stien A., Fuglei E., Ims R.A., Yoccoz N.G. \& Pedersen Å.O. 2013. Climate events synchronize the dynamics of a resident vertebrate community in the High Arctic. Science 339, 313-315, doi: 10.1126/science.1226766.

Hansson R. \& Thomassen J. 1982. Isbjørnbinner med unger $i$ Bogen hiområde, Kongsøya, Svalbard-en etologisk grunnstudie. 
(Polar bears with cubs in the Bogen denning area, Kongsøya, Svalbard-an ethological base study.) Rapportserie 12. Oslo: Norwegian Polar Institute.

Harington C.R. 1968. Denning habits of the polar bear (Ursus maritimus Phipps). Canadian Wildlife Service Report $5,1-30$.

Johnson C.J., Nielsen S.E., Merrill E.H., McDonald T.L. \& Boyce M.S. 2006. Resource selection functions based on use-availability data: theoretical motivation and evaluation methods. Journal of Wildlife Management 70, 347-357, doi: 10.2193/0022-541x.

Laidre K.L., Stirling I., Lowry L.F., Wiig Ø., HeideJørgensen M.P. \& Ferguson S.H. 2008. Quantifying the sensitivity of Arctic marine mammals to climate-induced habitat change. Ecological Applications 18, 97-125, doi: 10.1890/06-0546.1.

Larsen T. 1972. Air and ship census of polar bears in Svalbard (Spitsbergen). Journal of Wildlife Management 36, 562-570, doi: $10.2307 / 3799089$.

Larsen T. 1985. Polar bear denning and cub production in Svalbard, Norway. Journal of Wildlife Management 49, 320-326, doi: 10.2307/3801524.

Larsen T. 1986. Population biology of the polar bear (Ursus maritimus) in the Svalbard area. Norsk Polarinstitutt Skrifter 184 Oslo: Norwegian Polar Institute.

Lentfer J.W. 1975. Polar bear denning on drifting sea ice. Journal of Mammalogy 56, 716-718, doi: 10.2307/ 1379497.

Liston G.E. \& Elder K. 2006. A distributed snow-evolution modeling system (SnowModel). Journal of Hydrometeorology 7, 1259-1276, doi: 10.1175/jhm548.1.

Liston G.E., Perham C.J., Shideler R.T. \& Cheuvront A.N. 2016. Modeling snowdrift habitat for polar bear dens. Ecological Modelling 320, 114-134, doi: 10.1016/j. ecolmodel.2015.09.010.

Lone K., Aars J. \& Ims R.A. 2013. Site fidelity of Svalbard polar bears revealed by mark-recapture positions. Polar Biology 36, 27-39, doi: 10.1007/s00300-012-1235-y.

Lønø O. 1970. The polar bear (Ursus maritimus Phipps) in the Svalbard area. Norsk Polarinstitutt Skrifter 149. Oslo: Norwegian Polar Institute.

Maindonald J. \& Braun W.J. 2010. Data analysis and graphics using R. 3rd edn. Cambridge: Cambridge University Press.

Mauritzen M., Derocher A.E. \& Wiig Ø. 2001. Space-use strategies of female polar bears in a dynamic sea ice habitat. Canadian Journal of Zoology-Revue Canadienne de Zoologie 79, 1704-1713, doi: 10.1139/cjz-79-9-1704.
Messier F., Taylor M.K. \& Ramsay M.A. 1994. Denning ecology of polar bears in the Canadian Arctic Archipelago. Journal of Mammalogy 75, 420-430, doi: 10.2307/1382563.

Nagelkerke N.J.D. 1991. A note on a general definition of the coefficient of determination. Biometrika 78, 691-692, doi: 10.1093/biomet/78.3.691.

Pearce J. \& Ferrier S. 2000. Evaluating the predictive performance of habitat models developed using logistic regression. Ecological Modelling 133, 225-245, doi: 10.1016/ S0304-3800(00)00322-7.

Ramsay M.A. \& Stirling I. 1986. On the mating system of polar bears. Canadian Journal of Zoology 64, 2142-2151, doi: 10.1139/z86-329.

R Development Core Team 2018. R: a language and environment for statistical computing. Vienna: R Foundation for Statistical Computing.

Reistad M., Breivik Ø., Haakenstad H., Aarnes O.J., Furevik B.R. \& Bidlot J.-R. 2011. A high-resolution hindcast of wind and waves for the North Sea, the Norwegian Sea, and the Barents Sea. Journal of Geophysical Research-Oceans 116, C05019, doi: 10.1029/2010jc006402.

Reistad M., Haakenstad H., Furevik B. \& Haugen J.E. 2015. NORA10-final report 2015. The atmospheric part. Oslo: Norwegian Deepwater Programme.

Stien A., Ims R.A., Albon S.D., Fuglei E., Irvine R.J., Ropstad E., Halvorsen O., Langvatn R., Loe L.E., Veiberg V. \& Yoccoz N.G. 2012. Congruent responses to weather variability in High Arctic herbivores. Biology Letters 8, 1002-1005, doi: 10.1098/rsbl.2012.0764.

Stocker T.F., Qin D., Plattner G.K., Tignor M., Allen S.K., Boschung J., Nauels A., Xia Y., Bex B. \& Midgley B. (eds.) 2013. Climate change 2013. The physical science basis. Contribution of Working Group I to the fifth assessment report of the Intergovernmental Panel on Climate Change. Cambridge: Cambridge University Press.

Van Pelt W.J.J., Kohler J., Liston G.E., Hagen J.O., Luks B., Reijmer C.H. \& Pohjola V.A. 2016. Multidecadal climate and seasonal snow conditions in Svalbard. Journal of Geophysical Research-Earth Surface 121, 2100-2117, doi: 10.1002/2016JF003999.

Wiig Ø. 1998. Survival and reproductive rates for polar bears at Svalbard. Ursus 10, 25-32, doi: 10.2307/3873105.

Wood S.N. 2006. Generalized additive models: an introduction with $R$. Boca Raton, FL: Chapman and Hall.

Zeyl E., Aars J., Ehrich D. \& Wiig Ø. 2009. Families in space: relatedness in the Barents Sea population of polar bears (Ursus maritimus). Molecular Ecology 18, 735-749, doi: 10.1111/j.1365-294X.2008.04049.x. 